Journal of Animal and Veterinary Advances 10 (2): 251-261, 2011

ISSN: $1680-5593$

(C) Medwell Journals, 2011

\title{
Adoption of Innovations and Best Management Practices among Dairy Farmers in the Eastern Mediterranean Region of Turkey
}

\author{
${ }^{1}$ Ismet Boz, ${ }^{1}$ Cuma Akbay, ${ }^{2}$ Sinan Bas and ${ }^{3}$ Dilek Bostan Budak \\ ${ }^{1}$ Department of Agricultural Economics, ${ }^{2}$ Department of Animal Sciences, \\ Kahramanmaras Sutcu Imam University, 46100 Kahramanmaras, Turkey, \\ ${ }^{3}$ Department of Agricultural Economics, Cukurova University, Adana, Turkey
}

\begin{abstract}
This study analyzes the adoption of innovations and best management practices among dairy farmers in the Eastern Mediterranean Region of Turkey. A stratified sample of 160 dairy farmers were interviewed and the extent to which farmers' socioeconomic characteristics and information-seeking behavior influenced their decision to adopt the predetermined innovations and best management practices were investigated. Results showed that the age of farmers, income level, investment and owning improved breeds of animals positively influenced adoption. Among the information-seeking variables assessed, the use of the internet and contacts with extension personnel, private veterinarians and agricultural faculty members all influenced adoption levels.
\end{abstract}

Key words: Adoption of innovations, diffusion of innovations, livestock, dairy farming,veterinarians, Turkey

\section{INTRODUCTION}

Livestock production is one of the cornerstones of the agricultural sector in most developing countries. The contributions livestock make to farm operations have been emphasized by many studies, some of which are as follows: livestock provides the basic meat and dairy products needed by the urban and rural households and makes significant contributions to the textile and leather industries (Yurdakul et al., 1999); livestock utilizes farm products which have no value either for human nutrition or as raw material for food industries (plants, leaf remains and residues that would otherwise not be used) (Randolph et al., 2007); livestock increases labor productivity and capacity use ratio of farm buildings; livestock utilizes less advantaged lands such as meadows and pastures which are not suitable for farm machinery operation; livestock reduces the influences of natural and economic risks on farms and provides manure which increases soil fertility (Karagolge, 2001; Akbay and Boz, 2005); livestock increases cash availability to farms within a year (Hoddinott, 2006; Yurdakul et al., 1999) and livestock provides traction power for transportation and crop production (Powell et al., 1998). Overall, livestock make remarkable contributions toward food security and sustainable development (Sansoucy et al., 1995). Livestock production in Turkey accounts for approximately $25 \%$ of total agricultural production (TSA, 2008). The sector has a significant contribution and potential for Turkey's rural development in terms of production, processing and marketing. Through these processes, many goods and services are provided and thousands of people employed in the rural and also urban areas of the country (Boz and Akbay, 2005).

Although, modern and intensive livestock farming is developing, especially surrounding large consumer centers, traditional livestock farming is a predominant rural livelihood in places where land is not suitable for cropping due to limiting topographic and soil conditions. Both the low level of productivity and international competition has reduced the viability of this kind of livestock production.

The products of dairy farms are crucial for human nutrition and the government has implemented several support programs to improve the livestock sector; however, dairy farming in Turkey has faced a number of unprecedented problems which have dramatically decreased the number of dairy animals since 1990. The Eastern Mediterranean region of Turkey has also had a rapid decrease in the number of dairy farms as many have gone out of business.

Although, farm organizations and scientists have raised the issue, governments over the last two decades have not succeeded in promoting adequate measures or implementing the proper supporting policies for the

Corresponding Author: Ismet Boz, Department of Agricultural Economics, Kahramanmaras Sutcu Imam University, 46100 Kahramanmaras, Turkey 
livestock sector both generally and for dairies specifically. Either inefficient government policies or complex socioeconomic conditions in rural areas have caused the total number of dairy animals to decrease from 6.1-4.4 million during 1991-2008. In the same period, the total number of dairy animals in the Eastern Mediterranean region decreased from $270,000-180,000$ (TSA, 2008). To overcome these issues, the government has implemented a set of support programs through decisions of the Council of Ministers. Two major decisions were: the decision for livestock support for the 2000-2004 Period (Official Gazette, 2000); the decision for livestock support for 2005-2010 Period (Official Gazette, 2005). According to these decisions, governmental support was provided for fodder crop growing, purchasing of improved breeds of animals, artificial insemination, milk production and processing, meat production and processing and related facilities. Unlimited and unconditional support for the agricultural sector is no longer a favored policy approach. This issue was also discussed in the European Council Meeting held in June 2003 and radical reforms for the Common Agricultural Policy (CAP) were adopted. According to these reforms the new agricultural policy would consider consumers' and taxpayers' preferences and provide flexible support for farmers to adjust their production according to market demand.

The reforms suggest that the majority of farm support would be independent of production level and they must encourage farmers to produce commodities considering food security, environmental protection and animal health (European Commission, 2005). The best decision between production and farm supports would encourage farmers toward more market-oriented production, make them more competitive and provide a stable income for European Union (EU) farmers (European Commission, 2005). Support for large farmers would gradually be decreased while support for those who apply environmentally friendly practices and give priority to animal health would receive higher support. The new reforms were aimed to be consistent with the criteria of the World Trade Organization (European Commission, 2005). To adjust its agricultural policy to the CAP of the EU, Turkey must also apply the adopted farm policy reforms in the negotiations process for full membership of the EU. For this reason, the livestock policies in Turkey must also consider consumer demands, environmental protection, animal health and competition. To survive in these conditions, especially within a domestically and internationally competitive market, farmers who adopt innovations and apply best management practices are assumed to have a greater chance of remaining in the market. The current study is part A of a four-section research project supported by the Turkish Scientific Research Council (in Turkish, TSRCTUBITAK). The project was aimed to determine factors influencing the adoption and diffusion of innovations and application of best management practices among animal farms in the Eastern Mediterranean region of Turkey, focusing on dairy farming (Part A), beef cattle farming (Part B), sheep farming (Part C) and goat farming (Part D). Project finding also aimed to provide useful information for the Ministry of Agriculture and Rural Affairs (MARA) which is the sole public institution promoting innovations and developing extension programs for rural communities in Turkey.

In the diffusion and adoption literature, many studies have focused on the adoption and diffusion models of Rogers (1995), Feder et al. (1981) and Nowak (1982). According to Rogers model, an innovation is defined an idea, practice or object that is perceived as new by the individual or other unit of adoption.

Adoption is defined as a decision to make full use of an innovation as the best course of action available while diffusion is the process by which an innovation is communicated through certain channels over time among the members of a social system. Adoption is an individual decision and as the number of adopters in a social system increases the diffusion rate also increases. Because adoption is an individual decision, different characteristics of individuals may influence their adoption process. Rogers divided these characteristics into three main categories: socioeconomic characteristics, personality values and communication behavior. Each of these categories includes a number of generalizations that have been the explanatory variables of many studies in agricultural economics and rural sociology.

Considering empirical studies conducted in different countries, Feder et al., 1981) developed an adoptiondiffusion model which assumes that adoption of agricultural innovations in developing countries is influenced by seven major factors: farm size, tenure, labor availability, credit constraint, risk and uncertainty, human capital and sociological and other factors. Similar to these two models, Nowak (1982) used an adoption and diffusion model which mostly addressed factors influencing the adoption of conservation practices. According to Nowak's model, individuals' decisions on adoption are related to social-psychological, farm structural, ecological and institutional factors and many studies have chosen their explanatory variables from these factors. Empirical studies have shown that adoption of innovations and best management techniques influence farm performance 
in the long term and that adoption is influenced by many factors. A study conducted in 15 milk-producing states of the USA (El-Osta and Morehart, 1999), showed that the adoption of a capital-or management-intense technology increased dairy operations production performance and lowered their costs. Foltz and Chang (2002) found that using recombinant bovine Somatotropin (rbST) among Connecticut dairy farms had a positive effect on milk production and adoption of rbST was significantly higher among younger and more educated farmers that owned larger dairy herds. Barham et al. (2004) also found that among Wisconsin dairy farmers the larger farms with complementary feeding technologies were more likely to adopt rbST. A study by Lapar and Ehui (2004) stressed the importance of adopting dual-purpose forages as hedgerow species among smallholder farmers in the Philippines uplands and found that farmers who had more education, higher income and access to credit were more likely to adopt the selected management practice. Gebremedhin et al. (2003) found that household resource endowment, market integration and crop integration were significant factors that influenced adoption of improved forage technologies in crop-livestock mixed systems in the Ethiopian highlands.

In an Iranian study, Rezvanfar (2007) showed that information input, information output, farmer intra-system communication, farmer-researcher communication, farmerextensionist communication, availability of input facilities and overall knowledge level of dairy farming had positive influences on the adoption of dairy farming technologies. Breustedt et al. (2007) searched the adoption of Genetically Modified (GM) oilseed rape among German farmers and found that GM attributes, neighboring farmer attitudes towards GM cropping and number of farmer and farm characteristics had influence on prospective adoption. Matuschke and Qaim (2008) investigated the adoption of hybrid pearl milled in India and found that education, distance to main information sources, market infrastructure and the increasing role of private seed companies were significant factors to influence adoption. Ali and Abdulai (2010) study showed that adoption of GM cotton varieties positively influenced cotton yield and household income whereas negatively influenced pesticides use among farmers operating in Punjab province of Pakistan.

Although, dairy farming makes important contributions to food security and sustainable development in Turkey, factors affecting the adoption of innovations and best management technologies have not been sufficiently investigated. A study conducted in Aydin province divided adopter categories into three sections (low, medium and high level adopters) to determine whether there were significant associations between the variable representing these categories and other selected variables. The results showed significant associations between adopter categories and education, age, farming experience, social participation and empathy. Cicek et al. (2008) applied the same method and found significant associations between the variable representing adoption levels and each of the socioeconomic factors: enterprise scale, education level of farmer, work experience, living standards, association membership, openness to outer culture, use of mass media and empathy.

The present study differs from the above two studies in two ways: one is the use of a large variety of innovations and best management practices and the second is the employment of an econometric model which can explain the extent to which socioeconomic factors and information-seeking behavior influence farmers' decisions to apply these practices. The primary purpose of this paper was to determine the factors influencing the adoption of innovations and best management practices among dairy farmers operating in the Eastern Mediterranean region of Turkey. More specifically, the study was intended to address the following objectives:

- To determine socioeconomic characteristics and information-seeking behavior of dairy farmers

- To determine the adoption levels of innovation and best management practices among dairy farmers

- To determine the extent to which socioeconomic characteristics and information-seeking behavior influence the adoption of innovations and best management practices

- To develop recommendations to accelerate adoption of innovations and best management practices among dairy farmers

Results of this study are expected to be useful input for researchers, policy makers and extension organizations.

\section{MATERIALS AND METHODS}

The main materials of this study were provided from questionnaires conducted by face to face interviews with dairy farmers of the Eastern Mediterranean region of Turkey. Earlier research in the field, information from public and private institutions and subject-matter experts' opinions were also included in the materials of this study. The target population to whom the results of this study will generally apply is all dairy farms operating in the research area. The sampling, data collecting and data analysis procedures are described. 


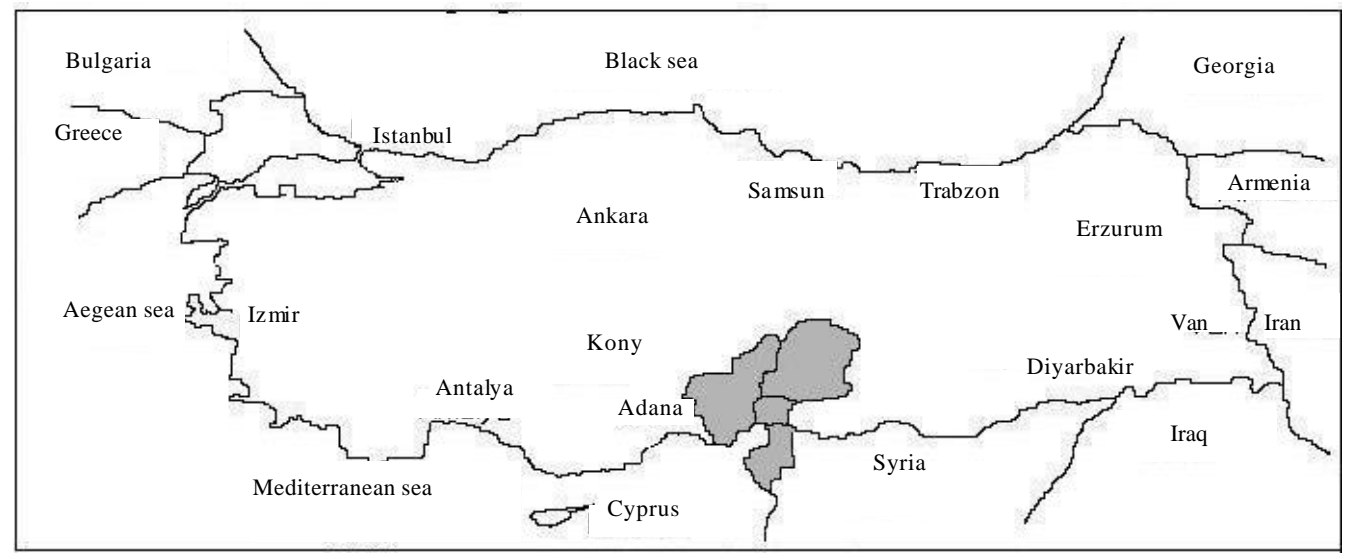

Fig. 1: Map of Turkey and shaded areas show the Eastern Mediterranean region where this research was conducted

Sampling procedures: To ensure an accurate sample, first determined the Eastern Mediterranean region districts and villages in which dairy farming is the predominant income source for rural families. There are four provinces in the region: Adana, Hatay, Osmaniye and Kahramanmaras. Administratively, each province has a number of districts and a large number of villages are connected to these districts.

The MARA is organized in every province and district as province and district directorates, respectively. We First made four visits to province directorates to determine the districts where dairy farming is the main income source on the basis of this information we chose the Central, Ceyhan and Kozan districts from province Adana; the Central, Kirikhan and Iskenderun districts from province Hatay; the Central, Turkoglu and Goksun districts from province Kahramanmaras and the Central, Bahce and Duzici Districts from Province Osmaniye as the most representative locations. Then contacted each district's agricultural directorate to determine the villages that represented the overall situation of dairy farmers. Three villages from each district (i.e., a total of 36 villages) were selected considering socioeconomic conditions, the distance from the district center, the population of the village and the potential of dairy farming (Fig. 1).

The Farm Record System from who provided 36 lists of farmers with their number of dairy animals and this constituted our accessible population. Considering the frequency distribution of the number of dairy animals that farmers owned, the accessible population was divided into three strata: farmers with $<10$ with $11-25$ and with $>25$ animals. Using stratified sampling determination formula of Yamane with 0.05 mean error and 95\% confidence interval $(\mathrm{t}=1.645)$, the sample size for this study was calculated as 154 . This number was proportionally divided into three strata and respondents from each stratum were randomly selected. Each respondent had an equal and independent chance of being included in the sample. The sample size was calculated as:

$$
\mathrm{n}=\frac{\mathrm{N} \sum \mathrm{N}_{\mathrm{h}} \mathrm{S}_{\mathrm{h}}^{2}}{\mathrm{~N}^{2} \mathrm{D}^{2}+\sum \mathrm{N}_{\mathrm{h}} \mathrm{S}_{\mathrm{h}}^{2}}, \quad \mathrm{D}^{2}=\frac{\mathrm{e}^{2}}{\mathrm{t}^{2}}
$$

Where:

$\mathrm{n}=$ Sample size

$\mathrm{N}=$ Accessible population

$\mathrm{N}_{\mathrm{h}}=$ Size of each stratum

$\mathrm{S}_{\mathrm{h}}=$ Standard deviation within a stratum

$\mathrm{D}^{2}=$ Desired variance

e $=$ Accepted error from the mean $(5 \%)$

$\mathrm{t}=\mathrm{t}$-value from the accepted confidence interval $(5 \%)$

Some respondents could not be found or refused to answer the questionnaire thus additional respondents with the same number of dairy animals were contacted to enable adequate completion of the survey. At the end of data collection there was a total of 160 usable questionnaires.

Data collection: A data collection questionnaire was developed which considered earlier research in the field as well as subject-matter experts' opinions. It consisted of three sections: section one included questions about socioeconomic characteristics of farmers; section two included communication behavior and section three included questions about dairy farming, innovations and/or best management practices. The innovations and/or best management practices covered in the data collection instrument were decided by an extensive review of literature and informal contacts with opinion leaders and subject-matter experts. Previously completed research (Duzgunes and Elicin, 1986; Taylor, 1995; Nell et al., 1998; Yavuz, 2006; MARA, 2006) was considered for 
construction of the data collecting instrument. Among the selected innovations and/or best management practices were artificial insemination; use of concentrated feeds, vitamins, proteins and silage; regular use of veterinary services; inoculation; growing legume crops; using insurance for animals; owning milking machinery and automatic watering and feeding of animals. A total list of these practices and their application levels in the research area are shown in Table 3.

In the socioeconomic characteristics section of the questionnaire, variables such as age, education, income level, cooperative membership, participation in village administration, farm investments in the last 3 years, farm size and number of dairy animals included. Information to seeking behavior variables, however were reading newspapers, listening to radio, watching television, using the Internet, meeting with other farmers in the village, travels to a county center, travels to a province center, contacts with agricultural extension personnel, contacts with private veterinarians, contacts with an agricultural faculty and participation in different dairy farming extension activities. Data were collected in JanuaryJune 2008. Most interviews were conducted at the sites of the farmers' operations. The village head-man or his assistants accompanied the researcher to establish a trustworthy and friendly atmosphere. It took approximately half an hour to complete a questionnaire.

Data analyses: The first objective of the study was to determine socioeconomic characteristics and informationseeking behavior of the respondents; descriptive statistics including means, standard deviations were used to accomplish this. The second objective was to determine the degrees of innovation adoption among the respondents; descriptive statistics including frequency percentages being the best procedure were used. The third and fourth objectives were to determine the extent to which selected socioeconomic characteristics and information-seeking behavior influenced the adoption of innovations among dairy farmers thus the ordered probit procedure was the best approach to accomplish these objectives. To construct the dependent variable of the study, 32 dairy farming innovations were determined. Considering the frequency distribution of the responses to the question of whether or not farmers adopted these innovations three adoption categories were formed.

Those who adopted $<11$ innovations were assigned to the low-level adoption category, those who adopted 12-20 innovations were assigned to the medium-level and those who adopted $>20$ innovations were assigned to the high level. Similar naturally ordered categories have been used in other studies (Khattak et al., 1992; McLean-Meyinsse, 1997; Abdel-Aty, 2000; Boz and Akbay, 2005). The dependent variable in the ordered probit model was coded as $0=$ low-level adoption, $1=$ medium-level and $2=$ high level. The model can be expressed as:

$$
\begin{gathered}
y^{*}=\beta^{\prime} x_{i}+\varepsilon, \varepsilon \sim N(0,1) \\
y=0 \text { if } y^{*} \leq 0, y=1 \text { if } 0<y^{*} \leq \mu_{1} \\
y=2 \text { if } \mu_{1}<y^{*} \leq \mu_{2}
\end{gathered}
$$

Where:

$y^{*}=$ Denotes the unobserved dependent variable

$\beta^{\prime}=$ Denotes the vector of coefficients

$\mathrm{x}_{\mathrm{i}}=$ Denotes the vector of independent variables

$\varepsilon=$ Denotes the vector of normally distributed error terms $N[0,1]$

$\mathrm{y}=$ Denotes the observed dependent variable as the likelihood of innovation adoption

$\mu=$ Denotes the threshold values of the three levels of innovation adoption

The threshold values vary with individual respondents. Respondents with similar socioeconomic characteristics or information-seeking behavior are expected to have similar threshold values due to the Central Limit Theorem (Maddala, 1983; Greene, 1993).

If the error term is normally distributed across observations, the likelihood of the individual respondents choosing a specific ranking is expressed as below (Greene, 1993; McLean-Meyinsse, 1997; Abdel-Aty, 2000; Chen et al., 2002):

$$
\begin{gathered}
\operatorname{Prob}(\mathrm{y}=0)=\Phi\left(-\beta^{\prime} \mathrm{x}\right) \\
\operatorname{Prob}(\mathrm{y}=1)=\Phi\left(\mu_{1}-\beta^{\prime} \mathrm{x}\right)-\Phi\left(-\beta^{\prime} \mathrm{x}\right) \\
\operatorname{Prob}(\mathrm{y}=2)=\Phi\left(\mu_{2}-\beta^{\prime} \mathrm{x}\right)-\Phi\left(\mu_{1}-\beta^{\prime} \mathrm{x}\right)
\end{gathered}
$$

where, $\Phi$ denotes the cumulative probability function of a standard normal distribution. The likelihood of dependent variable $y_{i}$ falls in the jth threshold category can be expressed as:

$$
\begin{array}{r}
\operatorname{Prob}\left(y_{i}=j\right)=\Phi\left(\mu_{j}-\beta^{\prime} x_{i}\right)- \\
\Phi\left(\mu_{j+1}-\beta^{\prime} x_{i}\right), j=0,1,2, \ldots J
\end{array}
$$

where, $\mu_{\mathrm{j}}$ and $\mu_{\mathrm{j}+1}$ express the lower and upper threshold values for category $j$, respectively. The log likelihood function is the sum of the individual respondents' $\log$ probabilities and is expressed as:

$$
\mathrm{L}=\sum_{\mathrm{j}=1}^{\mathrm{j}} \sum_{\mathrm{y}_{1}=\mathrm{j}} \log \left(\phi\left(\mu_{\mathrm{j}}-\beta^{\prime} \mathrm{x}_{\mathrm{i}}\right)-\phi\left(\mu_{1}-\beta^{\prime} \mathrm{x}_{\mathrm{i}}\right)\right)
$$

Marginal effects were calculated to determine how much each of the independent variables changes the likelihood of respondents falling in each of the three categories of the dependent variables. The marginal effects for an ordered probit model can be calculated as (Liao, 1994; Chen et al., 2002): 


$$
\frac{\partial \mathrm{P}(\mathrm{R}=\mathrm{y})}{\partial \mathrm{x}_{\mathrm{k}}}=\left[\phi\left[\mu_{\mathrm{j}-1}-\sum_{\mathrm{k}-1}^{\mathrm{k}} \beta_{\mathrm{k}} \mathrm{x}_{\mathrm{k}}\right]-\phi\left[\mu_{\mathrm{j}}-\sum_{\mathrm{k}-1}^{\mathrm{k}} \beta_{\mathrm{k}} \mathrm{x}_{\mathrm{k}}\right] \beta_{\mathrm{k}}\right.
$$

where, $\partial \mathrm{P} / \partial \mathrm{x}_{\mathrm{k}}$ denotes the partial derivation of the likelihood with respect to independent variables $x_{k}$. If a marginal effect has a positive sign it implies that the likelihood of respondents falling in a specific category of the dependent variable increases with $\mathrm{x}_{\mathrm{k}}$. However, if a marginal effect has a negative sign, it implies the opposite. The marginal effects across the three categories of dependent variables will sum to zero by cancelling one another.

\section{RESULTS AND DISCUSSION}

Of the respondents, $43 \%$ were $35-50$ years of age with average $44.58 ; 61 \%$ had elementary school education and $45 \%$ fell in the low income category (Table 1 ). There were $33 \%$ with cooperative membership, $18 \%$ participated in the village administration and $36 \%$ made farming investments in the last 3 years. The average farm size was 70.23 decares; the average number of animals per farm was 14 improved breeds, 1.94 native varieties and 5.34 hybrid varieties. Of the farmers, $71 \%$ had improved breeds, $49 \%$ had native animals and $19 \%$ had hybrid animals. Of the respondents, $36 \%$ read newspapers at least once a week and $42 \%$ several times a year, $63 \%$ listened to radio several times a week, $86 \%$ watched television every day, $29 \%$ used the internet several times a month and the rest almost never used the internet (Table 2). Of farmers, $57 \%$ met with other farmers in the village at least once a week, $64 \%$ traveled to a county center once a week and $46 \%$ traveled to a province center several times a year. About $13 \%$ had contacts with extension personnel once a month, $31 \%$ had contacts with private veterinarian once a month, $13 \%$ had contacts with an agricultural faculty several times a year and $10 \%$ took farming training once a year. The second objective was to determine the levels of innovation and best management practices adoption among dairy farmers. For this purpose, 32 innovations/best management practices of dairy farming were identified and included in the data collection questionnaire.

Respondents were asked whether or not they applied each of these practices (Table 3 ). Of the 32 items, utilizing veterinary services was applied by the highest percentage of farmers (99.4\%). This was followed by using concentrated feeds (94.4\%) and registering dairy animals (94.4\%). The majority of farmers also applied the following practices: colostrum feeding for newborn calves (89.4\%), vaccination against mad cow disease $(88.8 \%)$, artificial
Table 1: Socioeconomic characteristics of dairy farmers

\begin{tabular}{|c|c|c|}
\hline Definition of the variables and their codes & $\begin{array}{l}\text { Name of } \\
\text { the variables }\end{array}$ & Mean \pm SD \\
\hline Age (continuous variable) & Age & $44.58 \pm 12.76$ \\
\hline Younger than $35=1 ; 0$ otherwise & & $0.27 \pm 0.450$ \\
\hline $35-50=1$; otherwise & & $0.43 \pm 0.500$ \\
\hline Older than $50=1,0$ otherwise & & $0.30 \pm 0.460$ \\
\hline Education level & Education & \\
\hline Illiterate $=1 ; 0$ otherwise & & $0.07 \pm 0.250$ \\
\hline Elementary school $=1 ; 0$ otherwise & & $0.61 \pm 0.490$ \\
\hline Higher than elementary $=1 ; 0$ otherwise & & $0.32 \pm 0.470$ \\
\hline Income level & Income & \\
\hline Low $=1 ; 0$ otherwise & & $0.45 \pm 0.490$ \\
\hline Medium $=1 ; 0$ otherwise & & $0.44 \pm 0.500$ \\
\hline High $=1 ; 0$ otherwise & & $0.12 \pm 0.320$ \\
\hline Cooperative membership & Cooperative & \\
\hline Member $=1 ; 0$ otherwise & & $0.30 \pm 0.460$ \\
\hline Participation in village administration & Administration & \\
\hline Participated $=1 ; 0$ otherwise & & $0.18 \pm 0.390$ \\
\hline Investments in the last 3 years & Investment & \\
\hline Invested $=1 ; 0$ otherwise & & $0.36 \pm 0.410$ \\
\hline Farm size (continuous variable) & Farm size & $70.23 \pm 156.38$ \\
\hline No land $=1 ; 0$ otherwise & & $0.18 \pm 0.380$ \\
\hline$<50$ decares $=1 ; 0$ otherwise & & $0.51 \pm 0.500$ \\
\hline $50-150$ decares $=1 ; 0$ otherwise & & $0.21 \pm 0.410$ \\
\hline$>150$ decares $=1 ; 0$ otherwise & & $0.11 \pm 0.310$ \\
\hline $\begin{array}{l}\text { Number of improved breeds } \\
\text { (continuous variable) }\end{array}$ & Culture & $14.00 \pm 44.73$ \\
\hline Owned culture variety cows $=1 ; 0$ otherwise & & $0.71 \pm 0.460$ \\
\hline $\begin{array}{l}\text { Number of native cows } \\
\text { (continuous variable) }\end{array}$ & Native & $1.94 \pm 3.440$ \\
\hline Owned native cows $=1 ; 0$ otherwise & & $0.49 \pm 0.500$ \\
\hline $\begin{array}{l}\text { Number of hybrid cows } \\
\text { (continuous variable) }\end{array}$ & Hybrid & $5.34 \pm 17.89$ \\
\hline Owned hybrid cows $=1 ; 0$ otherwise & & $0.19 \pm 0.390$ \\
\hline
\end{tabular}

insemination (86.4\%), owning improved breeds (75.6\%) and vaccination against anthrax $(66.9 \%)$. Of the 32 innovations selected for this study, only 8 were applied by $>50 \%$ of the farmers (Table 3 ). The remaining 24 innovations were applied by $<50 \%$ of respondents. Another remarkable finding was that the majority of farmers were not aware of two innovations: vaccination against triangle $(61.9 \%)$ and removing extra nipples from calves $(59.4 \%)$.

The third objective was to determine the extent to which socioeconomic characteristics and informationseeking behavior influenced farmers' adoption of dairy farming innovations and best management practices. Data analyses showed that of 160 farmers in the sample, 84 $(52.2 \%)$ were low level, $55(34.4 \%)$ were medium-level and $21(13.1 \%)$ were high level adopters of innovations and best management practices.

The ordered probit procedure was used to accomplish this objective (Table 4 and 5) with the socioeconomic characteristics model is shown in Table 4 . The estimated chi-square coefficient $\left(\chi^{2}\right)$ of the model was 119.84 (degrees of freedom $=8$ ) and it was significant $(\mathrm{p}<0.01)$. The threshold coefficient ( $\mu=2.087$ ) of the model was also significant $(p<0.01)$ indicating that the order among the 
Table 2: Information-seeking behavior of dairy farmers

\begin{tabular}{|c|c|c|}
\hline Definition of the variables and their codes & $\begin{array}{l}\text { Name of } \\
\text { the variable }\end{array}$ & Mean \pm SD \\
\hline \multicolumn{3}{|l|}{ Reading newspaper } \\
\hline At least once a week $=1 ; 0$ otherwise & Newspaper 1 & $0.36 \pm 0.48$ \\
\hline Once a month $=1 ; 0$ otherwise & Newspaper 2 & $0.22 \pm 0.42$ \\
\hline Several times a y ear $=1 ; 0$ otherwise & Newspaper 3 & $0.42 \pm 0.49$ \\
\hline \multicolumn{3}{|l|}{ Listening to radio } \\
\hline Several times a week $=1 ; 0$ otherwise & Radio 1 & $0.64 \pm 0.48$ \\
\hline Several times a month $=1 ; 0$ otherwise & Radio 2 & $0.13 \pm 0.34$ \\
\hline Several times a y ear $=1 ; 0$ otherwise & Radio 3 & $0.23 \pm 0.42$ \\
\hline \multicolumn{3}{|l|}{ Watching television } \\
\hline Every day $=1 ; 0$ otherwise & Television & $0.86 \pm 0.3$ \\
\hline \multicolumn{3}{|l|}{ Using the internet } \\
\hline Several times a month $=1 ; 0$ & In & \pm 0.37 \\
\hline Almost never $=1$; & Intemet 2 & $0.71 \pm 0.45$ \\
\hline \multicolumn{3}{|l|}{ Meeting with other farmers in the village } \\
\hline At least once a week $=1 ; 0$ otherwise & Other farmers 1 & $0.57 \pm 0.49$ \\
\hline Several time & Other farmers 2 & $0.37 \pm 0.48$ \\
\hline Several times a week $=1 ; 0$ otherwise & Other farmers 3 & $0.05 \pm 0.22$ \\
\hline \multicolumn{3}{|l|}{ Travel to county center } \\
\hline Once a week $=1 ; 0$ otherwise & County 1 & $0.64 \pm 0.48$ \\
\hline Several times a month $=1 ; 0$ otherwise & County 2 & $0.32 \pm 0.46$ \\
\hline Several times a y ear $=1 ; 0$ otherwise & County 3 & $0.04 \pm 0.20$ \\
\hline \multicolumn{3}{|l|}{ Travel to province center } \\
\hline erwise & Prov & $0.31 \pm 0.46$ \\
\hline Seve & & $0.46 \pm 0.50$ \\
\hline Once a & & $0.23 \pm 0.4$ \\
\hline \multicolumn{3}{|l|}{ Contact with extension personnel } \\
\hline Once a month $=1 ;$ & 11 & $0.13 \pm 0.33$ \\
\hline Several time & Exten & $0.28 \pm 0.45$ \\
\hline More seldom $=1 ; 0$ otherwise & Extension 3 & $0.59 \pm 0.49$ \\
\hline \multicolumn{3}{|l|}{ Contact with private veterinarian } \\
\hline Once a month $=1 ; 0$ otherwise & Vet 1 & $0.31 \pm 0.46$ \\
\hline Several times a y ear $=1 ; 0$ otherwise & Vet 2 & $0.25 \pm 0.43$ \\
\hline More seldom $=1 ; 0$ otherwise & Vet 3 & $0.44 \pm 0.49$ \\
\hline \multicolumn{3}{|l|}{ Contact with an agricultural faculty } \\
\hline Several times a year $=1 ; 0$ otherwise & Faculty & $0.13 \pm 0.33$ \\
\hline \multicolumn{3}{|l|}{ Participating in farming training act } \\
\hline Once a year $=1 ; 0$ otherwise & Training & \\
\hline
\end{tabular}

three adopter categories of dairy farming innovations and best management practices is natural. Eight independent variables were entered into the model and four were significant $(\mathrm{p}<0.05)$ : age, income, investments and culture varieties.

Since, all of these variables had positive signs, then as they increased so their likelihood of being high level adopters of dairy farming innovations increased also. In contrast, farming experience, education, cooperative membership and farm size had no influence on adoption (Table 4). The marginal effects for significant socioeconomic variables can be interpreted as follows. Respondents' age increased their likelihood of being high and medium level adopters by 0.22 and $0.49 \%$, respectively; however, their likelihood of being low-level adopters decreased by $0.71 \%$.

The marginal effect for income shows that farmers with higher income had $71.8 \%$ higher likelihood of being high level adopters and 32.0 and $39.8 \%$ lower likelihoods of being medium and low level adopters, respectively. The marginal effects for investments showed that farmers who made more investments had 9.0 and $14.2 \%$ greater likelihood of being high and medium level adopters, respectively.

Those who made less investments had $23.3 \%$ smaller likelihood of being low level adopters. Finally, the marginal effect for improved breeds of animals showed that those who own more culture variety animals had 0.4 and $0.9 \%$ higher likelihood of being high and medium level adopters and had $1.3 \%$ less likelihood of being low level adopters. The model including information-seeking variables (Table 5) gave estimated $\chi^{2}=116.96$ (degrees of freedom $=8 ; \mathrm{p}<0.01)$. The threshold coefficient $(\mu=1.977)$ of the model was also significant $(\mathrm{p}<0.01)$ indicating that the order among the three adopter categories of dairy farming innovations is natural.

Eight independent variables were entered in the model and four were significant $(\mathrm{p}<0.05)$. The significant variables were use of the Internet, contacts with extension personnel, contacts with private veterinarians and contacts with an agricultural faculty and all had positive signs.

This finding verifies that as farmers tended to use the Internet more, make more contacts with extension personnel, private veterinarians and faculties of agriculture then their likelihood of being high level adopters of dairy farming innovations increased. However, reading newspapers, use of television, use of radio and travels to province centers had no significant influence on adoption.

The marginal effects for significant informationseeking variables can be interpreted as follows. If respondents used the internet more then their likelihood of being high or medium-level adopters increased by 24.9 and $23.3 \%$, respectively.

In contrast, their likelihood of being low level adopters decreased by $48.2 \%$. The marginal effect for contact with extension personnel showed that those who had more contact had 8 and $2 \%$ higher and $28 \%$ lower likelihood of being high, medium and low level adopters, respectively.

The marginal effects for visiting private veterinarians showed that farmers who had more visits had 10.0 and $26.0 \%$ higher and $36.0 \%$ lower likelihood of being high, medium and low level adopters, respectively. Finally, the marginal effect for contact with a faculty of agriculture showed that those who had more contacts had 20.0 and $22.0 \%$ greater and $42.0 \%$ smaller likelihood of being high, medium and low-level adopters, respectively. 
J. Anim. Vet. Adv., 10 (2): 251-261, 2011

Table 3: Dairy farming innovations and best management practices application levels

\begin{tabular}{|c|c|c|c|c|c|c|}
\hline \multirow[b]{2}{*}{ Dairy farming innovations } & \multicolumn{2}{|c|}{ Applied } & \multicolumn{2}{|c|}{ Not applied } & \multicolumn{2}{|c|}{ Not aware } \\
\hline & $\mathrm{N}$ & $(\%)$ & $\mathrm{N}$ & $(\%)$ & $\mathrm{N}$ & $(\%)$ \\
\hline Involvement in live animal board & 55 & 34.4 & 82 & 51.2 & 23 & 13.4 \\
\hline Regular use of veterinarian services & 159 & 99.4 & 1 & 0.6 & 0 & 0.0 \\
\hline Silage making and feeding & 53 & 33.1 & 107 & 66.9 & 0 & 0.0 \\
\hline Holding an animal kept for breeding certificate & 33 & 20.6 & 107 & 66.9 & 20 & 12.5 \\
\hline Growing fodder crops & 62 & 38.8 & 98 & 61.2 & 0 & 0.0 \\
\hline Animal insurance & 27 & 16.9 & 133 & 83.1 & 0 & 0.0 \\
\hline Owning improved breeds of animals & 121 & 75.6 & 39 & 24.4 & 0 & 0.0 \\
\hline Artificial insemination & 139 & 86.9 & 21 & 13.1 & 0 & 0.0 \\
\hline Embryo transfer for herd breeding & 2 & 1.2 & 112 & 70.0 & 46 & 28.8 \\
\hline Using concentrated feeds & 151 & 94.4 & 9 & 5.6 & 0 & 0.0 \\
\hline Owning milking machine & 51 & 31.9 & 109 & 68.1 & 0 & 0.0 \\
\hline Using vitamins for animal feeding & 68 & 42.5 & 87 & 54.4 & 5 & 3.1 \\
\hline Automatic watering & 13 & 8.1 & 140 & 87.5 & 7 & 4.4 \\
\hline Automatic feeding & 8 & 5.0 & 145 & 90.6 & 7 & 4.4 \\
\hline Animal registration & 151 & 94.4 & 9 & 5.6 & 0 & 0.0 \\
\hline Using minerals for animal feeding & 63 & 39.4 & 91 & 56.9 & 6 & 3.7 \\
\hline Fortifying native pasture hay with urea & 14 & 8.8 & 98 & 61.2 & 48 & 30.0 \\
\hline $\begin{array}{l}\text { Fortifying native pasture hay with } \\
\text { molasses-urea mixtures }\end{array}$ & 8 & 5.0 & 84 & 52.5 & 68 & 42.5 \\
\hline Vaccination against tuberculosis & 54 & 33.8 & 33 & 20.6 & 73 & 45.6 \\
\hline Vaccination against brucellosis & 68 & 42.5 & 23 & 14.4 & 69 & 43.1 \\
\hline Vaccination against mad cow disease & 142 & 88.8 & 9 & 5.6 & 9 & 5.6 \\
\hline Vaccination against triangle & 41 & 25.6 & 20 & 12.5 & 99 & 61.9 \\
\hline Vaccination against charbon & 107 & 66.9 & 39 & 24.4 & 14 & 8.8 \\
\hline Vaccination against anthrax & 65 & 40.6 & 56 & 35.0 & 39 & 24.4 \\
\hline Credit use & 31 & 19.4 & 129 & 80.6 & 0 & 0.0 \\
\hline Colostrum feeding for newbom calves & 143 & 89.4 & 9 & 5.6 & 8 & 5.0 \\
\hline Dehorning calves & 29 & 18.1 & 87 & 54.4 & 44 & 27.5 \\
\hline Removing extra nipples from calves & 14 & 8.8 & 51 & 31.9 & 95 & 59.4 \\
\hline Buy ing live animals under a veterinarian control & 59 & 36.9 & 90 & 56.2 & 11 & 6.9 \\
\hline Considering roughage to concentrate ratios of feeds & 59 & 36.9 & 101 & 63.1 & 0 & 0.0 \\
\hline Considering pure protein content of feeds & 24 & 14.9 & 87 & 54.4 & 49 & 30.6 \\
\hline Considering metabolic energy content of feeds & 14 & 8.8 & 76 & 46.5 & 70 & 43.8 \\
\hline
\end{tabular}

Table 4: Ordered probit estimates for the probability of innovation adoption by socioeconomic characteristics

\begin{tabular}{|c|c|c|c|c|c|c|}
\hline \multirow[b]{2}{*}{ Variables } & \multirow[b]{2}{*}{ Coefficient $^{1}$} & \multirow[b]{2}{*}{ SE } & \multirow[b]{2}{*}{$\mathrm{p}$} & \multicolumn{3}{|c|}{ Marginal effects } \\
\hline & & & & Low level & Medium level & High level \\
\hline Constant & 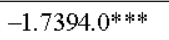 & 0.508301 & 0.0006 & - & - & - \\
\hline Age & $0.020016^{* * *}$ & 0.009867 & 0.0425 & -0.0071 & 0.0049 & 0.0022 \\
\hline Experience & 0.001174 & 0.002530 & 0.6427 & -0.0004 & 0.0003 & 0.0001 \\
\hline Education 3 & 0.481738 & 0.283646 & 0.0894 & -0.1616 & 0.0993 & 0.0623 \\
\hline Income 3 & $2.514470^{* * * * * * *}$ & 0.566354 & 0.0000 & -0.3979 & -0.3203 & 0.7182 \\
\hline Cooperative & 0.001241 & 0.001245 & 0.3187 & -0.0004 & 0.0003 & 0.0001 \\
\hline Investment & $0.695201 * * * *$ & 0.241697 & 0.0040 & -0.2326 & 0.1426 & 0.0900 \\
\hline Land & 0.001946 & 0.001298 & 0.1341 & -0.0007 & 0.0005 & 0.0002 \\
\hline Improved breeds & $0.035967^{* * * * * * * 1}$ & 0.008229 & 0.0000 & -0.0128 & 0.0088 & 0.0040 \\
\hline$\mu$ & 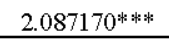 & 0.285577 & 0.0000 & - & - & - \\
\hline
\end{tabular}

Log likelihood function $=-95.57$; Restricted $\log$ likelihood $=-155.50 ; \chi^{2}(8)=119.84, p<0.01 ;{ }^{1}: * * *$ Significant at $p<0.05$ and $* * * p<0.01$

Table 5: Ordered probit estimates for the probability of innovation adoption by information-seeking behavior

\begin{tabular}{|c|c|c|c|c|c|c|}
\hline \multirow[b]{2}{*}{ Variables } & \multirow[b]{2}{*}{ Coefficient $^{1}$} & \multirow[b]{2}{*}{$\mathrm{SE}$} & \multirow[b]{2}{*}{$\mathrm{p}$} & \multicolumn{3}{|c|}{ Marginal effects } \\
\hline & & & & Low level & Medium level & High level \\
\hline Constant & $-1.402500^{\text {* * * * * }}$ & 0.324954 & 0.0000 & - & - & - \\
\hline News paper 1 & 0.467096 & 0.240967 & 0.0526 & -0.1831 & 0.1485 & 0.0346 \\
\hline Radio1 & 0.144140 & 0.235253 & 0.5401 & -0.0573 & 0.0481 & 0.0093 \\
\hline Television 1 & 0.402613 & 0.323642 & 0.2135 & -0.1593 & 0.1386 & 0.0207 \\
\hline Internet & $1.529560^{* \text { * * * * }}$ & 0.320291 & 0.0000 & -0.4829 & 0.2334 & 0.2495 \\
\hline Province & 0.064708 & 0.254694 & 0.7994 & -0.0257 & 0.0214 & 0.0044 \\
\hline Extension 1 & $0.760464^{* * *}$ & 0.299828 & 0.0112 & -0.2821 & 0.2021 & 0.0800 \\
\hline Vet1 & $0.981072^{* * * * *}$ & 0.250340 & 0.0001 & -0.3640 & 0.2665 & 0.0975 \\
\hline Faculty & $1.287720^{\text {* * * * * }}$ & 0.348178 & 0.0002 & -0.4189 & 0.2188 & 0.2001 \\
\hline$\mu 1$ & $1.977480^{* * * * *}$ & 0.250969 & 0.0000 & - & - & - \\
\hline
\end{tabular}

Log likelihood function $=-97.02 ;$ Restricted $\log$ likelihood $=-155.50 ; \chi^{2}(8)=116.96, p<0.01 ;{ }^{1}: * *$ Significant at $p<0.05$ and ${ }^{* * * *} p<0.01$ 


\section{CONCLUSION}

This study showed that dairy farms in the research area were mostly mixed farms owning an average of 70 decares of farming land, 14 cultured species, 1.94 native species and 5.34 hybrid species of dairy animals. Thus, the dairy farms in the Eastern Mediterranean region are larger than the average farm size in Turkey of 61 decares. However, excluding several large dairy farms (owning $>150$ animals) in the research area, most dairy farms own small numbers of animals and try to survive in a freemarket economy with limited government support. The majority of dairy farmers are not members of cooperatives or farmer unions, implying that every individual farmer is alone and has to accept input and milk prices of the market. Since, they operate as small units in the market and are not unified or in a cooperative, they have no power to bargain for lower input and higher milk prices. Thus, encouraging or supporting farmers to cooperate and unify should increase their viability. The adoption level of innovations and best management practices among dairy farmers was quite low. More than half of respondents were low level adopters and only $13 \%$ were high level, thus most dairy farmers were operating in a conventional manner. In this system, mixed farming including livestock and crop production takes place and an important part of the inputs for dairy animals are provided by the farm facilities. When farmers are not open to innovations and new ideas, low level adoption is inevitable and this inhibits productivity, quality and therefore marketing capacity of dairy enterprises. The findings concerning socioeconomic characteristics, support the hypothesis that as farmers get older have higher income make more investments and own more culture variety animals they tend to be high level adopters of innovations and best management practices. Although, the results with the last three variables were consistent with the earlier research, many studies have found that younger farmers adopt innovations more than older ones. In the research area there has been an occupational transition and many farmers, especially the younger ones have received education or training which has made it possible for them to get employment other than farming. Conventional farming is no longer an attractive livelihood for local youth. Thus those who remained in the sector are mostly older farmers and in order to remain in the market, they need to adopt innovations and apply best management practices in their farms.

\section{RECOMMENDATIONS}

Income level, investing in the farm and owning more improved breeds of animals positively influenced dairy farmers' adoption of innovations and/or best management practices. All these three attributes were related to productivity and profit margins of dairy products. Higher milk production and profit margins enables dairy farmers to make more investments in dairy farm innovations and/or best management practices as well as to convert their herds to improved breeds that provide more milk. These results verify that farmers who are willing to invest in dairy farming and convert their herds from native to improved breeds should be encouraged and even supported by low interest rates and long term loans. Unless there is proper government support, many dairy farms and particularly those who are unable to apply innovations and/or best management practices will go out of business.

This will also increase Turkey's dependence on foreign dairy products in the future. The principle of comparative advantage suggests that if costs are high and productivity levels are low it is worthwhile to purchase a product instead of producing it; however, considering the potential of natural resources and socioeconomic structure of the research area, the productivity and profit margins of dairy farmers could be increased with governmental support. The rural population in the locality should also be kept in the rural areas by supporting livelihoods such as dairy farming.

In terms of information seeking behavior, using the Internet, contacts with extension personnel, contacts with private veterinarians and contacts with agricultural faculties had a positive influence on adoption innovations and/or best management practices. Although, the majority of farmers ( $71 \%$ ) almost never used the Internet, this was a significant variable indicating that those who used the Internet were more innovative and had a tendency to apply best management practices in their dairy farms. Increasing farmers' access to the Internet may accelerate their information acquisition but this opportunity may only help a very small number of farmers, since the majority do not have the economic power to purchase computers or inadequate education to utilize this tool. Contacts with extension personnel, private veterinarians and agricultural faculties made it possible for farmers to receive information including on animal care, feeding, milking, grazing, diseases, milk processing, marketing and input providing.

Private veterinarians in the locality particularly provide a useful extension service. However, veterinarians researching as extension agents for the MARA province or district directorates are not able to regular visit farmers either due to lack of personnel or excessive bureaucratic research in their offices. This situation indicates that regular extension activities should be arranged to dairy farming areas to increase extension personnel contact hours with farmers. 


\section{REFERENCES}

Abdel-Aty, M.A., 2000. Using ordered probit modeling to study the effect of ATIS on transit ridership. Transport. Res. Part C: Emerg. Technol., 9: 265-277.

Akbay, C. and I. Boz, 2005. Turkey's Livestock Sector: Production, Consumption and Policies. Livest. Res. Rural Dev., Vol. 17, No. 9.

Ali, A. and A. Abdulai, 2010. The adoption of genetically modified cotton and poverty reduction in Pakistan. $\mathrm{J}$. Agric. Econ., 61: 175-192.

Barham, B.L., J.D. Foltz, D. Jackson-Smith and S. Moon, 2004. The dynamics of agricultural biotechnology adoption: Lessons from Rbst use in Wisconsin, 1994-2001. Am. J. Agric. Econ., 86: 61-72.

Boz, I. and C. Akbay, 2005. Factors influencing the adoption of maize in Kahramanmaras province of Turkey. Agric. Econ., 33: 431-440.

Breustedt, G., J. Muller-Scheebel and U. Latacz-Lohmann, 2007. Forecasting the adoption of GM oilseed rape: Evidence from a discrete choice experiment in Germany. J. Agric. Econ., 59: 237-256.

Chen, K., M. Ali, M. Veeman, J. Unterschultz and T. Lee, 2002. Relative importance rankings for pork attributes by Asian-origins consumers in California: Applying an ordered probit model to a choice-based sample. J. Agric. Applied Econ., 34: 67-79.

Cicek, H., Y. Cevger, Y. and M. Tandogan, 2008. Socioeconomic factors affecting the level of adoption of innovations in dairy cattle enterprises. Vet. J. Ank. Univ., 55: 183-187.

Duzgunes, O. and A. Elicin, 1986. Principles of Livestock Raising (Hayvan Yetistirme Ilkeleri in Turkish). Ankara University Press, Ankara.

El-Osta, H.S. and J.M. Morehart, 1999. Technology adoption decision in dairy production and the role of the herd expansion. Agric. Res. Econ. Rev., 28: 84-95.

European Commission, 2005. The common agricultural policy and the lisbon strategy. http://ec.europa.eu/ agriculture/lisbon/index_en.htm.

Feder, G., R. Just and D. Silberman, 1981. Adoption of agricultural innovations in developing countries: A survey. World Bank Staff Working Paper No. 444. The World Bank, Washington, DC. http://catalogue. nla.gov.au/Record/63952.

Foltz, J.D. and H. Chang, 2002. The adoption and profitability of rbST on connecticut dairy farms. Am. J. Agric. Econ., 84: 1021-1032.

Gebremedhin, B., M.M. Ahmed and S.K. Ehui, 2003. Determinants of adoption of improved forage technologies in crop-livestock mixed systems: Evidence from the highlands of Ethiopia. Trop. Grasslands, 37: 262-273.

Greene, W.H., 1993. Econometric Analysis. Macmillan Publisher, New York.
Hoddinott, J., 2006. Shocks and their consequences across and within households in rural Zimbabwe. J. Dev. Stud., 42: 301-321.

Karagolge, C., 2001. Agricultural Management. Ataturk University Faculty of Agriculture Press, Erzurum, Turkey.

Khattak, A., F. Koppelman and J. Schofer, 1992. Stated preferences for investigating commuters diversion propensity. Proceedings of the 71st Annual Meeting of Transportation Research Board, Washington DC.

Lapar, M.L.A. and S.K. Ehui, 2004. Factors affecting adoption of dual-purpose forages in the Philippine uplands. Agric. Syst., 81: 95-114.

Liao, T.F., 1994. Interpreting Probability Models: Logit, Probit and Other Generalized Linear Models. Sage Publications, Thousand Oaks, CA.

MARA, 2006. Livestock raising (hayvancilik-in Turkish). Ministry of Agriculture and Rural Affairs.

Maddala, G.S., 1983. Limited Dependent and Qualitative Variables in Econometrics. Cambridge University Press, Cambridge.

Matuschke, I. and M. Qaim, 2008. Seed market privatization and farmers' access to crop technologies: The case of hybrid pearl millet adoption in India. J. Agric. Econ., 59: 498-515.

McLean-Meyinsse, P.E., 1997. Factors influencing early adoption of new food products in louisiana and Southern Texas. J. Food Distrib. Res., 28: 1-10.

Nell, W.T., H.D. van Schalkwyg, J.H. Sanders, L. Schwalbach and C.J. Bester, 1998. Adoption of veterinary surgeon services by sheep and goat farmers in Qwaqw. Agrecon, 37: 418-435.

Nowak, P.J., 1982. Applicability of an adoption-diffusion model to resource conservation: A supporting view. Proceedings of the Annual Meeting of Rural Sociological Society, September 1982, San Francisco, California, pp: 21-21.

Official Gazette, 2000. Decision of the council of ministers about supporting livestock raising. Decision No. 2000/467, May 10, 2000, Official Gazette No. 24045.

Official Gazette, 2005. Decision of council of ministers about supporting livestock raising. Decision No. 2005/8503, February 24, 2005, Official Gazette No. 25737.

Powell, J.M., R.A. Pearson and J.C. Hopkins, 1998. Impacts of Livestock on Crop Production. In: Food, Lands and Livelihoods-Setting Research Agendas for Animal Science, Gill, M., T. Smith, G.E. Pollott, E. Owen and T.L.J. Lawrence (Eds.). Occasional Publication, British Society Animal Science, Edinburgh, UK., pp: 53-66.

Randolph, T.F., E. Schelling, E. Grace, C.F. Nicholson and J.L. Leroy et al., 2007. Invited rview: Role of livestock in human nutrition and health for poverty reduction in developing countries. J. Anim. Sci., 85: 2788-2800. 
Rezvanfar, A., 2007. Communication and socio-personal factors influencing adoption of dairy farming technologies among livestock farmers. Livest. Res. Rural Dev., Vol. 19, No. 3.

Rogers, E., 1995. Diffusion of Innovations. The Free Press, New York.

Sansoucy, R., M.A. Jabbar, S. Ehui and H. Fitzhugh, 1995. Keynote paper: The contribution of livestock to food security and sustainable development. Proceedings of the Joint FAO/ILRI Roundtable on Livestock Development Strategies for Low Income Countries. Feb. 27-March 02, International Livestock Research Institute, Addis Ababa, Ethiopia.
TSA, 2008. Livestock Statistics. Turkish Statistical Institution, Turky.

Taylor, R.E., 1995. Scientific Farm Animal Production: An Introduction to Animal Science. Prentice Hall Inc., New Jersey.

Yavuz, H.M., 2006. Basic Principles on Nutrition of Dairy Cows (Sut Sigirlarinin Beslenmesinde Temel Ilkeler-in Turkish). MAPA Press Ltd., Bursa, Turkey.

Yurdakul, O., D. Smith, A. Koc, F. Fuller and I. Yalcin et al., 1999. Livestock Supply and Feed Demand in Turkey an Evaluation of the Current Situation and Alternative Policy Scenarios. Agricultural Economics Research Institute Publication, Ankara, Turkey, pp: 122 . 